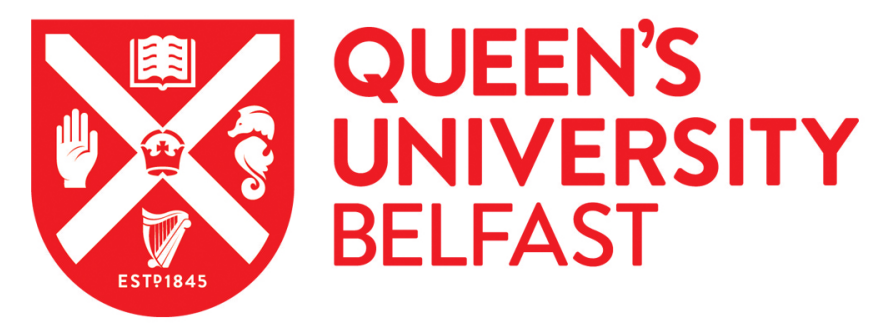

\title{
Crossings: Northern Irish Literature from Good Friday to Brexit
}

Lehner, S. (2020). Crossings: Northern Irish Literature from Good Friday to Brexit. In E. Falci, \& P. Reynolds (Eds.), Irish Literature in Transition, , 1980-2020 (Vol. Volume 6, pp. 136-151). Cambridge University Press.

\section{Published in:}

Irish Literature in Transition, , 1980-2020

\section{Document Version:}

Peer reviewed version

Queen's University Belfast - Research Portal:

Link to publication record in Queen's University Belfast Research Portal

\section{Publisher rights}

Copyright 2020 Cambridge University Press. This work is made available online in accordance with the publisher's policies. Please refer to any applicable terms of use of the publisher.

\section{General rights}

Copyright for the publications made accessible via the Queen's University Belfast Research Portal is retained by the author(s) and / or other copyright owners and it is a condition of accessing these publications that users recognise and abide by the legal requirements associated with these rights.

Take down policy

The Research Portal is Queen's institutional repository that provides access to Queen's research output. Every effort has been made to ensure that content in the Research Portal does not infringe any person's rights, or applicable UK laws. If you discover content in the Research Portal that you believe breaches copyright or violates any law, please contact openaccess@qub.ac.uk. 


\section{Crossings: Northern Irish Literature from Good Friday to Brexit}

\section{Stefanie Lehner}

Historically, culturally, and politically, Northern Irish literature has always been a nodal-point for multiple crossings. First articulated in 1987, Edna Longley pointedly captured these literary crosscurrents with the Denkbild [thought-image] of an open-ended 'cultural corridor', which is set against those political projects wishing to close it off, namely nationalism and unionism. Instead of fitting into these monolithic binary paradigms, for Longley, Northern Irish literature 'overspills borders and manifests a web of affiliation that stretches beyond any heartland - to the rest of Ireland, Britain, Europe'. ${ }^{1}$ This is reflected in the critical category of Northern Irish literature itself, which - depending on where it is taught or sold - straddles and thereby questions the categories of English, Irish, and British literature. Coined during the peak of the North's political conflict, Longley's notion of a cultural corridor resonates in the post-conflict and Brexit eras: negatively, perhaps in the prospect of a hard border returning to isolate Northern Ireland from the Republic or an Irish Sea border isolating it from Great Britain; positively, in that Northern Ireland's receptivity to Europeanness (evinced in the region's majority vote to remain in the EU) mirrors similar sentiments along the 'Celtic fringe' in the Republic and Scotland.

The 1998 Belfast or Good Friday Agreement can be said to both affirm and trouble the open-endedness of Longley's conception in a number of ways. In its endeavour to end the three-and-a-half-decades of war and violence, euphemistically known as 'The Troubles', the Agreement aimed to set up a nationalist and unionist power-sharing government in Northern Ireland as a basis for lasting peace. Yet, the consociational model that underpins the new devolved assembly naturalises rather than transcends the divisions of the two dominant ideological blocs. This threatens to occlude a vast range of other relations, positions, and 
concerns that constitute the 'web of affiliations' that Longley envisions. On the question of whether Northern Ireland should remain in the United Kingdom or become part of a united Ireland, the Agreement suggested an openness to both possibilities by stating that there would be no change without the consent of the majority. As a multi-party agreement that also entails an international agreement between the British and Irish governments, its strands establish both North-South and East-West institutions, thereby affirming Northern Ireland as 'a zone where Ireland and Britain permeate one another'. ${ }^{2}$

The affirmation of British-Irish relations is, however, as much political as it is economic, intending, at the time, to reintegrate Northern Ireland into the neo-liberal global dispensation by extending the free market principles of the British 'Third Way' westwards and the (at the time still roaring) Celtic Tiger northwards. ${ }^{3}$ Northern Irish poetry early on interrogated the progressivist logic of this new economic corridor, which suggested redevelopment and regeneration through multinational investment as the way forward for a society deemed 'backwards'. Sinéad Morrissey’s 'In Belfast' (2002), for instance, visualises the market-driven ideology that has taken on a life of its own, devoid of actual people: 'The inhaling shop-fronts exhale the length | and breadth of Royal Avenue, pause, | inhale again. The city is making money | on a weather-mangled Tuesday. ${ }^{4}$ In turn, Leontia Flynn's 'Belfast' (2008) captures the way in which the new attempts to replace the old: 'Belfast is finished and Belfast is under construction. | What was mixed grills and whiskeys (cultureless, graceless, leisureless) $\mid$ is now concerts and walking tours (Friendly! Dynamic! Various!). ${ }^{5}$ What such 'progress' can never achieve is cleverly foregrounded in Alan Gillis' eponymous poem:

They say that for years Belfast was backwards and it's great now to see some progress. 
So I guess we can look forward to taking boxes

from the earth. I guess that ambulances

will leave the dying back amidst the rubble

to be explosively healed. ${ }^{6}$

By reversing the arrow of time, Gillis foregrounds the ethical absences of such a teleological narrative of historical 'progress'. Resonant of Walter Benjamin's famous description of the 'Angel of History' who 'would like to stay, awaken the dead, and make whole what has been smashed' while he is 'irresistibly' blown backwards into the future, ${ }^{7}$ the speaker contemplates the impossibility of resurrecting 'those who have died or been injured' during the Troubles. ${ }^{8}$ In doing so, the poem questions the temporal logic underpinning the 1998 Agreement, which suggests that 'we can best honour them through a fresh start'.

The fascination with novelty and new beginnings that is suggested in the Agreement's 'fresh start' is registered in Morrissey's 'Tourism' (2002), which sets the desire for 'new symbols, | a new national flag' against the way in which the Troubles' past has been cordoned off and commodified for tourists, pretending 'as though it's all over and safe behind bus glass | like a staked African wasp'. ${ }^{10}$ Yet, as suggested by these examples, postAgreement literature remains acutely aware that the 'staked' past can still sting and that the peace process may have created a rather different and more narrow corridor than that envisioned by Longley: one that, in its complicity with a readymade futurity of global consumerism and neoliberal economics, resembles more a one-way street, as insinuated by the strategic street sign for the Agreement's 'Yes' campaign, reading 'Vote Yes. It's the way ahead'. ${ }^{11}$

Brexit reconfigures these fluid and complex dynamics that characterise the North's corridor. This occurs on multiple levels and in several directions, but the major question 
concerns the placement of the UK-EU border: whether it is drawn in the Irish Sea or on the island of Ireland (as per the 'backstop' in Prime Minister May's defeated 2019 plan), the North-South and East-West dimensions of the 1998 Agreement will be ruptured. The implications extend to affiliations and identity articulations, which are safeguarded in the Agreement's recognition that national identity and citizenship are not a matter of binary choice but fluid and multiple. ${ }^{12}$ For Irish nationalists, a 'hard' border will be understood to reimpose partition and reinvoke the troubled past, but an Irish Sea border will, in turn, alienate Ulster unionists. The unsettling of these dynamics extends to Scotland where nationalists there will question any special status granted or imposed on Northern Ireland in relation to the EU. In this regard, the demand for sovereignty implied in the Leave campaign's 'Take back control' slogan is exposed as out of place and out of time: the intertwined relations of Northern Ireland and Scotland mean that both within and between the two regions Brexit is less about self-determination and more about recognising the fragile bonds that constitute the Union. Arguably, this almost existential predicament has been overshadowed by security-related concerns over the types of opportunities and fears that a border will precipitate for loyalists and republicans in Northern Ireland and the very real threats that lie therein to the peace process as it has developed over the past two decades. Ironically, these fears are seemingly not shared by Northern Irish 'Leave' voters as the 2018 'Future of England Study' reveals that $87 \%$ of such voters 'see the collapse of the peace process as an acceptable price for Brexit' ${ }^{13}$

The uncertain and ambiguous position of Northern Ireland within Brexit is addressed in David Wheatley's poem 'Flags and Emblems' (2018), in which a 'man in a post office' questions if a 'Northern Irish fiver' is 'part of us' (presumably the United Kingdom) or 'Southern Ireland'. ${ }^{14}$ Both Northern Irish and Scottish banks have traditionally printed their own money, which is not classified as 'legal tender' in the rest of the UK and, as a result, 
often not recognised. As 'the postmaster' concludes, it is from 'somewhere anyway | in need of a cloot | to wipe itself down'. Wheatley's poem uses here the story of a malfunctioning sewage tanker in Crossgar, 'randomly | spraying clabbery glar', as what he describes as an 'over-obvious analogy for the resurgent English nationalism about to descend like a pall (of slurry) over Britain and Northern Ireland'. This image of English cross-contamination is, yet, juxtaposed with an emphasis on the specifics of Northern Irish locality ('gable-ends kerbstones'; 'flags on | the lampposts') and the use of several Scots vernacular forms in a poem that was itself first conceived when crossing from Belfast to Scotland. Thus, despite its deliberations on fixity - 'things mean | themselves and nothing | besides' - the poem enacts, and, in its own way, celebrates the inherent ambiguity and openness of Northern Ireland.

Even as the Brexit debate significantly complicates matters, Post-Agreement literature remains committed to Northern Ireland as a place of interchange that enables various crossings. However, rather than accepting the 'post' as a temporal marker that designates a distinct break with what came before, these texts raise awareness to what remains to be worked through and addressed: these unresolved issues, silences, and absences connote a period of troubled, stalled transition, suggesting a sense of suspension that seems reflected in Northern Ireland's repeatedly suspended devolved assembly. ${ }^{15}$ Indeed, suspension has remained one of the key critical categories for reading contemporary Northern Irish literature. Richard Kirkland's Literature and Culture in Northern Ireland since 1965: Moments of Danger (1996) proposed the Gramscian concept of the 'interregnum' to analyse Northern Ireland's 'crisis', which inspired John Brannigan's 2006 analysis of literary refractions of 'the paradoxical state of suspension which characterizes the interregnum'. ${ }^{16}$ These studies have paved the way for more recent discussions of suspension as an aesthetic category, most notably in Birte Heidemann's Post-Agreement Northern Irish Literature: Lost in a Liminal Space? (2016), but also evident in Maureen E. Ruprecht Fadem's The Literature of Northern 
Ireland: Spectral Borderlands (2015) as well as Declan Long's Ghost-Haunted Land: Contemporary Art and Post-Troubles Northern Ireland (2017). But while critics have suggested that this ongoing state of liminal suspension is a 'disabling condition', this chapter seeks to recover the recalcitrant dynamics of literary liminality as a crosscurrent to the homogenising and teleological thrust of the progress narratives underpinning both the Agreement and Brexit. ${ }^{17}$ This emphasis on the active energies suggested by the motif of crosscurrents allows a revision of the more passive concepts of the cultural corridor and suspension and foregrounds the potential of contemporary Northern Irish literature to establish new affiliations and reconciliatory discussions, and to undertake a dialogue between the temporal coordinates of a haunting past and a precarious 'fresh' future.

\section{Commemorative Corridors: Traversing Temporalities}

The unfinished business of the past haunts the Northern Irish peace process, which is reflected and refracted in post-Agreement literature. Public commemoration has been dominated by what Graham Dawson calls 'defensive remembering', 'where selective, discrepant and antagonistic narratives of the past clash and compete'. ${ }^{18}$ There are still very few inclusive public memorials - most of which occur in the form of, or within, texts: most notably, the ambitious Lost Lives project, which tells the stories of all those that died as a result of the Troubles. ${ }^{19}$ If Gillis' 'Progress', alongside other recent Northern Irish poetry, suggests alternative forms of commemoration, prose fiction has offered a more expansive space for what Graham-Dawson calls 'reparative remembering', which would enable 'an opening emotionally to the disavowed past, connecting and integrating traumatic histories, and engaging with the memory world of the other'. ${ }^{20}$ Such a remembering shows the capacity to reconcile the proleptic and retrospective tendencies that, Neal Alexander suggests, characterise pre- and post-Agreement Northern Irish fiction, in order to open up a 
commemorative corridor between the past and future that disrupts the progressivist teleology of the peace process as well as one-sided forms of defensive commemoration. ${ }^{21}$

Glenn Patterson's fictional oeuvre offers an indicative example of this notion of a commemorative corridor. Despite their differences, his novels seem equally concerned to exhume what he himself terms 'alternative histories' of his native city, Belfast, which have been subsumed by the dominant narrative of the Troubles. ${ }^{22}$ This interrogation of the past opens fresh perspectives on the unfolding future of the peace process. For instance, Patterson's The International (1999), is narrated retrospectively by Danny Hamilton, who revisits one day of his life in 1967 pre-Troubles Belfast as a barman at the eponymous hotel. Danny's narration encircles and thereby foregrounds the 'absence' of Peter Ward in his story, an International barman who was murdered by the UVF in June 1966 as one of the first victims of the conflict and whom Danny replaced: 'I wish it was not so, but guns do that, create holes which no amount of words can fill. ${ }^{23}$ Aware of the irrevocability of his death, Danny re-inscribes his absent presence by noting his personal connection with him: 'Peter Ward was eighteen when he died. I turned eighteen a fortnight after he was buried, a fortnight after I started work in the hotel. ${ }^{24}$ In aligning and thereby integrating their stories, Danny's recollection works as an act of 'reparative remembering', which also connects the events of the violent past with an anticipation of a non-violent future. The end of the novel suggests this through the 1994 announcement of the loyalist ceasefire by Gusty Spence, who was convicted of the murder of Ward. As he listens to Spence expressing 'the abject and true remorse of the Loyalist terror groups on whose behalf he was speaking', Danny's thoughts return to Ward, thereby connecting killer and victim, past and present, in a reconciliatory anticipation of the future: 'I believed him.' ${ }^{25}$

Despite its progressivist trajectory, moving from the pre-Troubles to the postAgreement, Patterson's Number 5 (2003) builds a socio-cultural and commemorative corridor 
by telling the stories of five successive occupants of a terraced house on the suburbs of Belfast from the 1950s to the millennium. These characters are representative of a diverse range of Northern Ireland's population and their move to this new location enables them to establish new affiliations that challenge established paradigms. For instance, the Chinese teenager Tan forms a friendship with the son of his Protestant neighbours, whose nickname is Tit, and together they insert themselves as ' $T$ ' $n$ ' $T$ ' into the walls of their neighbourhood, thereby subverting the codes of paramilitary sectarianism. Whilst every new family is eager to make a fresh start in the house by redecorating it, traces of the previous occupants stand as powerful reminders of the haunting presence of the past in the present. The irrevocable temporality of such memorial traces, which disrupt the linear progression of the novel, is embodied in the figure of Ivy Moore. This neighbour, as her name suggests, twines traces of the past with future changes: most notably through the act of remembering the occluded story of the first occupant, Stella, whose daughter suddenly returns at the close of the novel. ${ }^{26}$ In a comparable manner, Patterson unsettles the chronological delineation of Belfast's Peace Process in That Which Was (2004), a novel in which the amnesiac character Larry approaches a Presbyterian minister, Ken Avery, with the vague recollection of having committed murder during the Troubles. As Avery resolves to uncover the truth behind Larry's conviction of his guilt, Larry confides: 'I believe that memories come back to haunt you, even when someone has tried to erase them.' 27

The thriller was the predominant mode for representing the Troubles, ${ }^{28}$ and a notable number of peace process fictions have employed elements of the form, which has proven especially able to register the temporal and spatial crossings underpinning the Agreement, while contesting the notion that it could draw 'a line under the past'. As Patterson notes, in 2004 alone, three other novels came out that used the thriller genre to explore the unresolved business of the past in the post-Agreement present. ${ }^{29}$ Eoin McNamee's The Ultras confronts 
the controversial issue of the collusion between the security forces and paramilitaries, and David Park's Swallowing the Sun explores the impact that psychological and physical violence of the past have on its main character, Martin Waring, whose daughter dies after taking Ecstasy. Sean O'Reilly's The Swing of Things questions to what extent it is possible to leave a paramilitary past and prison sentence behind by following Noel Boyle to Dublin, where he tries to change by enrolling at university.

In these novels, the haunting past takes on an ethical force which conjures questions about responsibility, guilt, and justice. However, in keeping with the mystery element of the thriller, they also highlight the difficulty of conclusive truths and clear-cut morals, specifically regarding the roles of victim and villain. For instance, Stuart Neville's The Twelve (2010) actively foregrounds the problematic ethics of a broad conception of victimhood that can be seen to absolve those directly responsible for violence. ${ }^{30}$ The exparamilitary prisoner Gerry Fagan reflects in this novel that 'the politicians on the outside had bartered for his freedom, along with hundreds more men and women. They called people like him political prisoners. Not murders or thieves, not extortionists or blackmailers. Not criminals of any kind, just victims of circumstance'. ${ }^{31}$ The ethical force of these thrillers resides in the reparative remembrance they can afford by emphatically connecting with the memory world of the other: whether these stories are told by innocent victims, guilty perpetrators, or positions in between, they intimate 'the sense of a collective responsibility to narrate, listen and respond to the stories of the dead' ${ }^{32}$ The reconciliatory potential that such a sharing of stories can have on individuals and societies has been emphasised by storytelling initiatives and also in several recent plays, perhaps most forcefully by Owen McCafferty's Quietly (2012), which importantly revises the genre by staging a suspenseful encounter between a perpetrator and a victim. 
If the thriller has been notably transformed in recent literary post-Agreement literature, the past five years have also witnessed the embrace of magical realist elements, specifically in short stories by Northern Irish women writers. Like the crime thriller, the magical realist mode seems apt to register the traumatic excesses of the recent violent past, which occur in these stories in the form of supernatural, surreal, or fantastical elements or characters. ${ }^{33}$ For instance, Annie, the first-person narrator of Bernie McGill's 'No Angel' (2013), is haunted by the ghost of her recently deceased father who tries to forestall her putative 'love-across-the-barricades' relationship, as he and his deceased wife have not been able to overcome the sectarian murder of Annie's younger brother, James. Although Annie's relationship fails, the end of the story allows for a reconciliation between the past, present, and future when Annie recognises that her ghost-father found her mother and brother, who join her as spectral audience members to watch a performance, and he accepts her request to let her go into her own self-determined future: "“I won’t be told who to love by you," I said. ${ }^{34}$ In the Northern Irish literary imagination, this freedom of romantic choice, specifically in the form of a mixed marriage, has long functioned as a trope for a wider social reconciliation. ${ }^{35}$ The challenges of such cross-community relationships are suggested in Roisín O’Donnell's ‘Ebenezer's Memories’ or Jan Carson's ‘Children's Children’ (both 2016), the latter of which envisages the allegorical coming together of the last inhabitants of an island's split northern and southern sides as 'a brave new direction'. ${ }^{36}$ In contrast to this proleptic vista, many of these magical realist stories confine the repressed past to a contained space, such as the cupboard under the stairs in O'Donnell's 'Ebenezer's Memories', or the boxroom of Carson’s ‘Contemporary Uses for a Belfast Box Room’ (2016).

\section{Spatial Corridors: Border Crossings}


A number of recent post-Agreement fictions explore physical journeys as a means to internal crossings; these journeys confront their protagonists with unresolved issues of the past. This is already apparent in Patterson's rarely discussed thriller, The Third Party (2007), which is narrated retrospectively by an unnamed Northern Irish businessman who works for a plastics company. The novel focuses on the last day of his trip to Hiroshima where he meets a fellow countryman and writer, known only as 'Ike', who attends the conference 'Writing Out of Conflict 2004'. The double connotations of this conference title (which parallels the double meaning of the novel's title) draw attention to the ways in which both men, in their different ways, trade on Northern Ireland's post-conflict politics: while Ike has written himself out by having exploited other people's pain and stories to write about the Troubles, the narrator-businessman has exploited the 'messy peace' by making a dodgy deal with an (ex)paramilitary 'Brigadier' to dispose of his company's dangerously defective 'U-bag prototype', a self-sealing bag to replace clingfilm, thereby causing hurt, misery, and physical deformations to babies in Sardinia, where the faulty product was resold. ${ }^{37}$

This novel takes the action outside of Northern Ireland, which is important because Hiroshima provides a foil to Belfast's dealings with past tragedy that emphasises the need to confront one's guilty conscience. In his three visits to the A-Bomb museum, the narrator notices that 'it was impossible to pass through any part of the museum without your conscience or compassion snagging on something, ${ }^{38}$ The last part of the novel depicts the titular 'third party', that is, the party after the after-party, a space of alcohol-fuelled stylistic surrealism, but it also introduces a third party to the Northern pair: the Japanese couple, Tadao and Mami. These two locals, whom the Irish reading audience would largely encounter as foreigners, ${ }^{39}$ forge a surreal cultural corridor between Japan and Northern Ireland that forces the narrator to cross several boundaries at the close of the novel. Firstly, Tadao confronts him with what has been previously left silenced in the story, thereby 
exposing his repressed responsibility and guilt. Secondly, Mami seems to trigger the narrator's uncertain suicide, whereby, crossing from the realm of living to the putative dead, he feels rescued by the eagle he imagined seeing that morning: 'I saw it all, and all at once, as though the talons were carrying me not on, or up, but beyond, to where time ceased to have meaning' ${ }^{40}$ This alterative perspective accepts the need and necessity to 'tell ... the whole story' as truthfully as possible. ${ }^{41}$

The motif of the journey as a means for possible restoration, renewal, and redemption from residual responsibilities emerges as an important trope in David Park's more recent work. In The Truth Commissioner, James Fenton, a retired officer of the Royal Ulster Constabulary (RUC), envisages going 'away somewhere [to] come back whole and fresh, ready to move on'. ${ }^{42}$ Fenton is haunted by his guilty conscience for recruiting Connor Walshe, a teenage petty criminal, as an informer. Walshe disappears, and to atone Fenton journeys to a Romanian orphanage. Yet, rather than providing him the opportunity for a 'fresh start', his passage confronts him with the painful truth about his failed parental responsibility towards Connor. This topic is also the focus of Park's latest novel, Travelling in a Strange Land (2018), which follows Tom, a professional photographer and father of three, on his snow-covered journey from Belfast to Sunderland to bring back son Luke for Christmas. Like Fenton, Tom is haunted by the absent presence of a dead figure: his firstborn son, Daniel, whose substance abuse and penchant for stealing from his family caused his father to throw him out. Daniel disappeared for a time before his father found him dead in a shabby bare room. At his graveside, Tom feels 'in a no man's land between what should have been the future and the past that was and I don't know to which I belong'. ${ }^{43}$ However, the close of the novel suggests a release from his traumatic entrapment in this temporal suspension when he visits the Angel of the North shortly before arriving at Luke's: noticing 
how the Angel's wings 'somehow point to the future', Tom says 'a secret prayer, because I've finally found the words'. ${ }^{4}$

These literal journeys also bring to light transitions in identity that characterise the peace process period. Park's exploration of the complexities of fatherhood signals a shift in the articulation and agency of masculine identity: from one associated with violence, silent authority, and control to one underpinned by the ethos of non-violence, uncertainty, sympathy, and concern for the other. ${ }^{45}$ His concern with parenthood is also examined in The Light of Amsterdam (2012), which tells the stories of three different sets of protagonists who travel on the same flight from Belfast to Amsterdam for a long weekend. While they do not all meet, they are connected by their comparably strained, fractured relationships with their family travel companions. Through the fresh experiences and perspectives that Amsterdam offers, in their different ways, all characters experience a redemptive reconnection with their estranged family members, which is based both on unconditional love for one's children as well as respect for one's significant other and his/her story. ${ }^{46}$

These novels insinuate that this connection and sympathy with the other is not only enabled through the outside perspective afforded by a location outside Northern Ireland but also specifically through storytelling, the process of which is foregrounded in Lucy Caldwell's All the Beggars Riding (2013). In her attempt to come to terms with her deceased parents' clandestine love life across the Irish Sea that produced herself and her brother, the narrator, Lara Moorhouse, comes to realise the generative power of writing:

Writing my story, I think, in many ways saved my life. It certainly changed everything: the course of bitterness and recrimination and despair that I fear I was set upon. It let me forgive my mother, and let go of my father. [...] It taught me that writing isn't self-expression, vomiting self-pity onto the page. It's the taking and 
shaping of things, carefully, again and again, until they make a sort of sense that not only you but others can understand, and maybe benefit from. ${ }^{47}$

In emphasising the way in which storytelling creates a corridor not only between an isolated self and other (or, indeed, as Lara mentioned, 'other selves') ${ }^{48}$ but also among a wider audience, these reflections can be seen to gesture to the reconciliatory potentials of storytelling within the context of the Northern Irish peace process, emphasised, for instance, by the recent legacy-related Stormont House Agreement proposals, which include an Oral History Archive. ${ }^{49}$ In Caldwell's novel, Lara's writing enables her to cross not only imaginatively to her own past and parent's worlds but also, literally, to Belfast, where her father lived with his other, official family, and to connect there with her half-brother, 'and in a small way, help him too to let the past go'. ${ }^{50}$

These border crossings often work to confront the protagonists with repressed, halfforgotten memories of the Troubles. For instance, in Deirdre Madden's Time Present Time Past (2013), old photographs trigger for the middle-aged protagonist Fintan involuntary memories of 'his childhood in the North, where his granny had a little orchard' ${ }^{51}$ Set during the final year of the Celtic Tiger's boom, Fintan seeks to want to stop its storm of progress by turning, like Benjamin's Angel of History, to the past. When he and his sister cross the Irish border to revisit the old family farm at the close of the novel, they are able to reconcile the past with the present, making them aware of 'how completely over [the past] is: you can't really get at it again'. To which Fintan replies: 'And it can’t get at you either', emphasising the safety and security that distance from the past can bring. ${ }^{52}$ Accepting the pastness of the past opens the present to the future - and this is what this novel does through its strong omniscient narrator who predicts not only the Republic's immanent economic crash but also the future of Fintan's family. 
Such a temporal resolution is, however, problematic and problematised in texts set in the border regions, which were often the sites of intense conflict during the Troubles and continue to be haunted by the unfinished business of a raw and recent past. This transgressive gothic mode reverberates in the notably different imaginations of the two McCabes (no relation) of Clones, County Monaghan: Eugene and Patrick. ${ }^{53}$ But it is also evident in the work of the playwright Abbie Spallen, most of whose plays are set in small, conservative Northern border towns. Lally the Scut (2015) offers an appropriately grotesque allegorical examination of post-Agreement peace politics through the efforts of its eponymous protagonist who desperately seeks to rescue her son, who has fallen down a hole in a bog. Appealing for help, Lally is confronted by the self-serving opportunism of those in charge, and the intricacies of post-conflict politics, which bring endless hurdles for the rescue operation. The initial problem is that the location of the hole is in a field straddling the border, where it is 'impossible to tell [...] if it's in the North or the South' ${ }^{54}$ When the dig finally starts it is, in turn, halted as Republican politicians fear that the digging might unearth a 'Corpse of the disappeared'. ${ }^{55}$ If the border bog contains the imminent danger of the traumatic return of the violent past, however, it also contains hope for a fresh future through the rescue of the child.

The liminality of the border is enshrined through the right to cultural hybridity in the Agreement, which, as I've described, is placed under a new kind of pressure under the shadow of Brexit. The 'Brexit Short' by another Northern Irish playwright, Stacey Gregg, 'Your Ma's a Hard Brexit' (2017), which was commissioned by The Guardian, registers the generational ambivalences felt by the Protestant community about Brexit. The unnamed protagonist, filmed on a school run with a young boy, recalls teasing her father about the benefits of getting an Irish passport and told him that even Ian Paisley Junior, a leading Unionist MP and Leave campaigner, urged his constituents to apply for one. ${ }^{56}$ Yet despite the 
prospect of 'a united Ireland', as a middle-aged Protestant working-class woman from an interface area, she is keenly aware of the detrimental effects of past and present divisions through the border and peace walls (a topic explored in more detail in Gregg's 2015 play, Shibboleth). At the end, she suggests that the child embrace the possibilities of Northern Ireland's institutionalised 'cultural corridor': 'At the end of the day, if you've your head screwed on, get your Irish passport: you're European and your [sic] British. Go after the work. And sure, that's the best the young ones can hope for, isn't it? ${ }^{57}$ As the camera zooms out on the child, Gregg's short, like Spallen's play, seems to suggest that the limited hope for the future lies in the next generation.

With the prospect of Brexit, the future is certainly uncertain (pending a second referendum or a no-deal at the time of writing). Yet, as Siobhán Campbell emphasises in her poem 'Why Islanders don't kiss hello' (2017), despite feelings of betrayal and anxieties (which, in the poem, concern the cultural traditions of kissing hello), it is important to honour the Agreement's embrace of a risky common future: 'we've learned because we must, | being from the island of largesse, | to give that peck of venture in a shared future' ${ }^{58}$ Indeed, Brexit could transmogrify the future of the Northern corridor in radically new ways. If Brexit affirms the significance of the Agreement's dedication to keep the North's cultural corridor open, it reminds us, at the same time, 'that the political architecture of the archipelago is radically open-ended'. ${ }^{59}$ As Fintan O'Toole suggested in 2016, the new divisions created by Brexit might thus in turn facilitate a radical rethinking of the renewed affiliations and possibilities it created: 'To think, that is, about a new union - of Scotland, Ireland and Northern Ireland: SCINI.' This, O’Toole suggests, could also offer 'the only long-term solution to Northern Ireland's problem of double identity - the "British" part of that identity has always been much more Scottish than English' ${ }^{60}$ It will be interesting to see if the next generation of post post-Agreement authors will respond to these new affiliations and 
(re)awaken the long tradition of Irish-Scottish cross-currents for future use in the wake of Brexit. $^{61}$

${ }^{1}$ Edna Longley, The Living Stream: Literature and Revisionism in Ireland (Newcastle: Bloodaxe Books, 1994), p. 194. Longley's concept of the 'cultural corridor' was first articulated in her article 'Opening up: A New Pluralism', Fortnight, 256 (1987), 24-25. ${ }^{2}$ Longley, The Living Stream, p.195.

${ }^{3}$ See Aaron Kelly, 'Geopolitical Eclipse: Culture and the Peace Process in Northern Ireland', Third Text, 19.5 (2005), 545-553 (p. 548).

${ }^{4}$ Sinéad Morrissey, Between Here and There (Manchester: Carcanet, 2002), p. 13.

${ }^{5}$ Leontia Flynn, Drives (London: Cape Poetry, 2008), p. 2.

${ }^{6}$ Alan Gillis, Somebody, Somewhere (Oldcastle: Gallery Press, 2004), p. 55.

${ }^{7}$ Walter Benjamin, Illuminations, trans. by Harry Zohn (London: Pimlico, 1999), p. 249.

${ }^{8}$ The Agreement: Agreement Reached in the Multi-Party Negotiations (Good Friday Agreement), 10 April 1998, 'Declaration of Support', paragraph 2, < https://webarchive.nationalarchives.gov.uk/20121004213521/> [accessed 8 February 2019]

${ }^{9}$ The Agreement, 'Declaration of Support', paragraph 2.

${ }^{10}$ Morrissey, Between Here and There, 14.

${ }^{11}$ The 'YES' Campaign, The 'YES' Campaign Flyer (1998), <http://cain.ulst.ac.uk/issues/politics/docs/yes220598a.pdf> [accessed 18 August 2018]

${ }^{12}$ See The Agreement, 'Constitutional Issues', paragraph 1.

${ }^{13}$ Centre on Constitutional Change, 'Press Release', (8 October 2018), <www.centreonconstitutionalchange.ac.uk/news/press-release-may's- 'precious-union'-haslittle-support-brexit-britain> [accessed 13 January 2018]

${ }^{14}$ David Wheatley, 'Poetry in the age of Brexit', The Irish Times (23 June 2018), <www.irishtimes.com/culture/books/poetry-in-the-age-of-brexit-1.3536218> [accessed 10 January 2019]. Subsequent quotations from this poem are taken from this same webpage. 15 The Northern Irish Assembly was suspended five times since 1998 and at the time of writing (December 2018) it has been suspended since January 2017. 
${ }^{16}$ John Brannigan, 'Northern Irish Fiction: Provisionals and Pataphysicians', in A Concise Companion to Contemporary British Fiction, ed. by James F. English (Oxford: Blackwell, 2006), pp. 141-163 (p. 146).

${ }^{17}$ Birte Heidemann, Post-Agreement Northern Irish Literature: Lost in a Liminal Space? (Basingstoke: Palgrave Macmillian, 2016), p. 8.

${ }^{18}$ Graham Dawson, Making Peace with the Past? Memory, Trauma and the Irish Troubles (Manchester: Manchester University Press, 2007), p. 76.

${ }^{19}$ David McKittrick, Seamus Kelters, Brian Feeney, and Chris Thornton, Lost Lives: The Stories of the Men, Women and Children Who Died as a Result of the Northern Ireland Troubles (Edinburgh: Mainstream, 2001).

${ }^{20}$ Dawson, Making Peace with the Past, p. 77.

${ }^{21}$ Neal Alexander, 'Remembering to Forget: Northern Irish Fiction after the Troubles', Irish Literature Since 1990: Diverse Voices, ed. by Scott Brewster and Michael Parker

(Manchester and New York: Manchester University Press, 2010), pp. 272-283 (p. 274).

${ }^{22}$ Declan Burke, 'Review and Interview: The Rest Just Follows', Irish Examiner, 16 March 2014, <www.irishexaminer.com/lifestyle/artsfilmtv/books/the-rest-just-follows261920.html> [accessed 8 August 2018]

${ }^{23}$ Glenn Patterson, The International (London: Anchor, 1999), p. 318.

${ }^{24}$ Patterson, The International, p. 92.

${ }^{25}$ Patterson, The International, p. 318.

${ }^{26}$ See Heidemann's reading of Ivy as a human 'trace' in Post-Agreement Northern Irish Literature, p. 74.

${ }^{27}$ Glenn Patterson, That Which Was (London: Hamish Hamilton, 2004), p. 49.

${ }^{28}$ See Aaron Kelly, The Thriller and Northern Ireland Since 1969: Utterly Resigned Terror (Hampshire: Ashgate, 2005), p. 1.

${ }^{29}$ Patrick Hicks, ‘An Interview with Glenn Patterson', New Hibernia Review, 12.2 (Summer 2008), 106-119 (p. 107).

${ }^{30}$ The legal definition of a 'victim' is inclusivist in effect - see 'The Victims and Survivors (Northern Ireland) Order 2006' < https://www.legislation.gov.uk/nisi/2006/2953/contents> [accessed 8 February 2019]. It has been criticised by some politicians and civil society groups as eliding bystanders, 'innocent' victims and perpetrators - see, for instance, the submission by the South-East Fermanagh Foundation to the Northern Ireland Office's recent consultation on dealing with the past, <https://seff.org.uk/wp-content/uploads/2018/10/SEFF- 
${ }^{31}$ Stuart Neville, The Twelve (London: Harvill Secker, 2009), p. 7.

32 Alexander, 'Remembering to Forget', p. 280.

${ }^{33}$ See Dawn Miranda Sherratt-Bado, "'Things We'd Rather Forget”: Trauma, the Troubles, and Magical Realism in Post-Agreement Northern Irish Women's Short Stories', Open Library of Humanities, 4.2, (2018), 1-30 〈https://doi.org/10.16995/olh.247〉

${ }^{34}$ Bernie McGill, 'No Angel', Sleepwalkers (Belfast: Whittrick Press, 2013), pp. 39-48.

${ }^{35}$ See Joe Cleary, Literature, Partition and the Nation State (Cambridge: Cambridge University Press, 2002), pp. 97-141. See also Stefanie Lehner, 'Reconciliation and the Politics of Friendship in post-Troubles Literature', in The New Irish Studies: Twenty-First Century Critical Revisions, ed. by Paige Reynolds (Cambridge: Cambridge University Press, forthcoming).

${ }^{36}$ Roisín O’Donnell, ‘Ebenezer's Memories', Wild Quiet (Dublin: New Island Books, 2016), pp. 1-21; Jan Carson, 'Children's Children', Children's Children (Dublin: Liberties Press, 2016), pp. 184-190 (p. 185).

${ }^{37}$ Glenn Patterson, The Third Party (Belfast: Blackstaff Press, 2007), pp. 159-60.

${ }^{38}$ Patterson, The Third Party, p.50.

${ }^{39}$ This argument takes into consideration that the novel is published by Blackstaff Press, which is a local press.

${ }^{40}$ Patterson, The Third Party, p. 168.

${ }^{41}$ Patterson, The Third Party, p. 168.

${ }^{42}$ David Park, The Truth Commissioner (London: Bloomsbury, 2008), p.128.

${ }^{43}$ Park, Travelling in a Strange Land (London: Bloomsbury, 2018), p. 149.

${ }^{44}$ Park, Travelling in a Strange Land, p. 164.

${ }^{45}$ See Fidelma Farley, 'In the Name of the Family: Masculinity and Fatherhood in Contemporary Northern Irish Films', Irish Studies Review, 9.2 (2001), 203-13 (p. 203). See also Stefanie Lehner, 'Post-Conflict Masculinities: Filiative Reconciliation in Five Minutes of Heaven and David Park's The Truth Commissioner', Irish Masculinities: Critical Reflections on Literature and Culture, ed. by C. Magennis and R. Mullen (Dublin: Irish Academic Press, 2011), pp. 65-76.

${ }^{46}$ See Caroline Magennis, "“My Narrative Falters, as it Must”: Rethinking Memory in Recent Northern Irish Fiction', in Post-Conflict Literature: Human Rights, Peace, Justice, ed. by Chris Andrews and Matt McGuire (London: Routledge, 2016), pp. 31-42.

${ }^{47}$ Lucy Caldwell, All the Beggars Riding (London: Faber, 2013), p. 238.

${ }^{48}$ Caldwell, All the Beggars Riding, p. 8. 
${ }^{49}$ Northern Ireland Office, 'Consultation Paper: Addressing the Legacy of Northern Ireland's past' (May 2018)

https://assets.publishing.service.gov.uk/government/uploads/system/uploads/attachment_data /file/709091/Consultation_Paper_Addressing_the_Legacy_of_Northern_Irelands_Past.pdf [assessed 8 February 2019

${ }^{50}$ Caldwell, All the Beggars Riding, p. 238.

${ }^{51}$ Deirdre Madden, Time Present and Time Past (London: Faber and Faber, 2013), pp. 115116.

${ }^{52}$ Madden, Time Present, p. 222.

${ }^{53}$ While many of Patrick McCabe's novels are set in a fictionalised border region, it is specifically Breakfast on Pluto (1998) that deals with the Troubles, as do many of the stories of Eugene McCabe's Heaven Lies About Us (2005), which were written over the past 30 years.

${ }^{54}$ Abbie Spallen, Lally the Scut (London: Faber, 2015), p. 49.

55 Ibid., p. 84.

${ }^{56}$ Stacey Gregg, 'Your Ma's a Hard Brexit', The Guardian, 19 June 2017

<www.theguardian.com/stage/2017/jun/19/your-mas-a-hard-brexit-a-new-play-by-staceygregg-brexit-shorts>

${ }^{57}$ Ibid.

58 Siobhán Campbell, 'Why Islanders don't kiss hello', Heat Signature (Bridgend: Seren, 2017), p. 51.

${ }^{59}$ Fintan O’Toole, 'Three-state union may be answer to Brexit', The Irish Times, 26 July 2016, <www.irishtimes.com/opinion/fintan-o-toole-three-state-union-may-be-answer-to-brexit$\underline{1.2734041>}$ [accessed 20 September 2018]

${ }^{60} \mathrm{O}$ 'Toole, 'Three-state union may be answer to Brexit'.

${ }^{61}$ For a detailed discussion of Irish-Scottish crosscurrents, see Stefanie Lehner, 'Devolutionary States: Crosscurrents in Contemporary Irish and Scottish Fiction', in The Oxford Handbook of Modern Irish Fiction, ed. by Liam Harte (Oxford: Oxford University Press, forthcoming). 